\title{
Natural Moisturizer Based Formulation of Green Grass Jelly (Cyclea Barbata Miers) with Aloe Vera Addition
}

\author{
Santi Fitri Harianti ${ }^{*}$, Kun Harismah ${ }^{2}$ \\ ${ }^{1}$ Department of Chemical Engineering, University of Muhammadiyah Surakarta, Surakarta, Indonesia. \\ 2 Department of Chemical Engineering, University of Muhammadiyah Surakarta, Surakarta, Indonesia. \\ * Corresponding author: santifitriharianti12@gmail.com
}

\section{ARTICLE INFO}

Article history

Received May 2, 2020

Revised May 26, 2020

Accepted May 26, 2020

Available Online May 31, 2020

\section{Keywords}

Moisturizers

Aloe vera

Green grass jelly

Flavonoid

Antioxidant

\begin{abstract}
Moisturizer is one of cosmetics used for dry skin care and can make skin become moist and soft. Natural material can be used to maintain water content in the skin and soften skin is Aloe vera. Aloe vera contains minerals, vitamins A, C, E and B12. In addition to Aloe vera to maintain antioxidants in the skin is green grass jelly because it has flavonoid content. Content contained in Aloe vera and green grass jelly can be used for making natural moisturizers because at this time many moisturizers that contain harmful chemicals. This observation was to analyze differences in concentration of Aloe vera and green grass jelly on moisturizers and analyze antioxidant activity of green grass jelly. Method used in making this moisturizer is mixing with green grass jelly formulation $(2.5 \%$; $5 \% ; 7.5 \%)+$ Aloe vera $(2.5 \%, 5 \%, 7.5 \%, 10 \%)$, and non-sample formulation treatment. Analysis of this experimental data was qualitative on moisturizers and quantitatively to calculate levels of flavonoids in green grass jelly. Results of this study indicate that difference in concentration of Aloe vera + green grass jelly greatly affects parameters of good moisturizer used, and greater addition of green grass jelly concentration greater flavonoid content in moisturizer.
\end{abstract}

This is an open access article under the CC-BY-SA license.

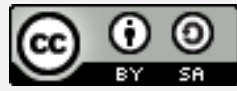

\section{Introduction}

The skin is the outermost part of the human body and serves to protect the body from outside influences. One that causes skin damage is free radicals [1]. Free radicals in the body are formed due to air pollution, ultraviolet light, unhealthy lifestyles and cigarette smoke. This can cause skin damage and the need for skin care such as the use of moisturizers [2].

Moisturizers are used to prevent the evaporation of water on the skin and make the skin moist and soft by forming a thin layer of fat on the surface of the skin [3]. The making of this moisturizer from natural ingredients namely green grass jelly and Aloe vera. The skin moisturizing formulation consists of Aloe vera to moisturize the skin, grass grass jelly leaves as an antioxidant, thickener, emulsifier and humectant so that it can maintain skin softness and moisture. The content of bioactive compounds in green grass jelly include polyphenols, flavonoids, chlorophyll, B-carotene, alkaloids, saponins, 
carbohydrates, tannins, steroids, and glycosides. Green grass jelly contains bioactive compounds that function as antioxidants, anti-inflammatory, antihypertensive, antidiabetic, antibacterial, and anticancer [4]. The flavanoid content of grass jelly significantly influences antioxidant activity and has a free radical effect [5]. In addition to green grass jelly, Aloe vera contains $99 \%$ of the total weight and contains $25 \%$ of the dry weight of monosaccharides and polysaccharides. Aloe vera also contains bradykinase, lignin, and vitamins, namely vitamins A, C, E, B12. The content of monosaccharides and polysaccharides is able to bind water in the air which functions as a humectant while lignin content of aloe vera gel has a high absorption ability into the skin making it easier to absorb the water content of Aloe vera extract to the skin and able to withstand the loss of liquid from the surface of the skin [6].

Aloe vera and green grass jelly extract have active ingredients that are expected to be a safe and effective moisturizing alternative for skin care.

\section{Methods}

\subsection{Research Methodology}

The research methodology used in this study is to use the complete random design Method 2 factors using 4 treatment variations of green grass jelly formula $(2.5 \% ; 5 \% ; 7.5 \%$; and $10 \%)+$ Aloe vera $(5 \%, 10 \%, 15 \%, 20 \%, 25 \%)$ and 1 treatment of formulations without green grass.

\subsection{Variable Research}

\subsubsection{Independent variable}

The free variables that this research used are:

a. Increase in green grass jelly concentrations: $0 \% 2.5 \%, 5 \%$, and $7.5 \%$

b. Added Aloe vera concentration: $0 \% 2.5 \%, 5 \%, 7.5 \%$, and $10 \%$

\subsubsection{Fixed variable}

The fixed variables used were the temperature with the following values:

a. Extraction temperature grass jelly: $50{ }^{\circ} \mathrm{C}$

b. Moisturizing manufacturing Temperature: $35{ }^{\circ} \mathrm{C}, 40^{\circ \mathrm{C}}$, and $70{ }^{\circ} \mathrm{C}$

\subsubsection{Dependent Variable}

The dependent variable is the parameter that will be observed when all test series have been carried out. In this study the parameters to be observed are the quality of the moisturizer and the level of effectiveness at each moisturizing concentration.

\subsection{Procedure Research}

\subsubsection{Green Grass Leaf Extraction}

Making grass jelly powder begins with washing fresh jelly leaves with cold water, then dried with an oven $50^{\circ} \mathrm{C}$ for 18 hours or until dry. Then the dried leaves are blended or grinded until smooth and sieved with a 200 mesh sieve. Grass jelly powder weighed 25 grams then put into $1000 \mathrm{ml}$ beaker glass and added $600 \mathrm{ml}$ of distilled water to heat using a hot plate until the temperature reaches $90^{\circ} \mathrm{C}$. Filter the grass jelly with cloth or filter paper, the results of the grass jelly extract are dried until then puree and grass jelly powder is put into the beaker.

\subsubsection{Aloe vera Gel Extraction}

Aloe vera is cleaned and brushing is then rinsed. Aloe vera base is cut about $1 \mathrm{~cm}$, then the skin is peeled. The Aloe vera gel is then rinsed several times with running water. Aloe vera gel in a blender until there 
are no lumps and then put in a plastic bottle and placed in the refrigerator.

\subsubsection{Procedure of Moisturizing}

The ingredients used were weighed using a digital scale, with the following composition: glycerin weighed as much as 10 grams, TEA weighed as much as 0.6 grams, and aquades as much as $169 \mathrm{ml}$ using a $250 \mathrm{ml}$ beaker (water phase or preparation 1), stearic acid 2.4 gram weighed, PEG-100 stearate glyceril monostearate weighed 4.8 gram, cetyl alcohol weighed 0.8 gram, isopropyl palmitate weighed 5 gram, using $100 \mathrm{ml}$ beaker (phase of fatty acid or preparation 2) . Both preparations are heated to a temperature of $70-75^{\circ} \mathrm{C}$ while stirring periodically, then (preparation of water phase 1) put in (preparation of fatty acid phase 2), stirring until homogeneous. Homogeneous preparations are mixed and stirred with a stirrer reaching a temperature of $40^{\circ} \mathrm{C}$ (preparation 3). Preservatives (nipagin) and perfume (Oil. Rosae) are weighed and then put into preparation 3 at $35^{\circ} \mathrm{C}$ and then stirred again for approximately one minute. Grass jelly powder with a concentration of $2.5 \%, 5 \%, 7.5 \%$ and Aloe vera with a concentration of $2.5 \%, 5 \%, 7.5 \%, 10 \%$ homogeneous according to the formulation, by taking non-sample moisturizers $60 \mathrm{ml}$ put into $250 \mathrm{ml}$ beaker glass then samples of grass grass jelly leaves and Aloe vera are inserted and homogenized, then after a homogeneous grass jelly moisturizer + aloe vera is put into a bottle and then kept on the ice shelf.

Gliserin

TEA

Aquades

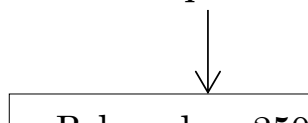

Beker glass $250 \mathrm{~m}$

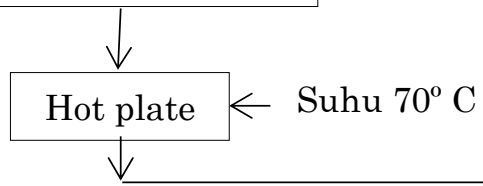

Asam stearat

Gliserin monostearat

Setil alkohol

Isopropil palmitat

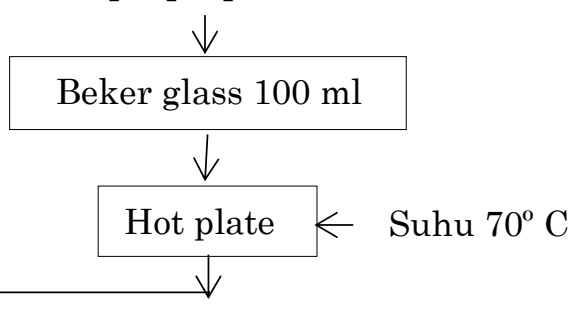

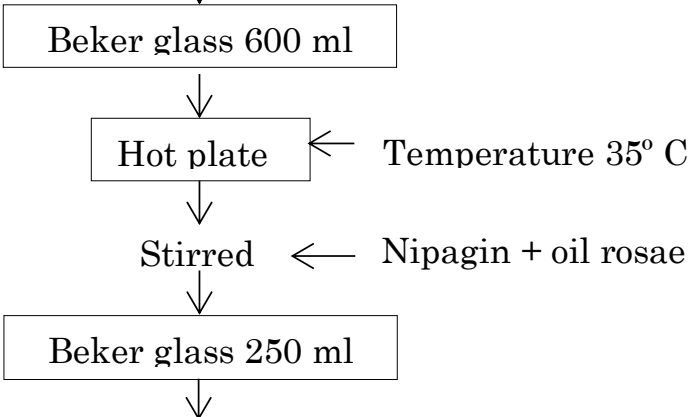

Green grass jelly leaves + aloe vera<smiles>[AlH2]</smiles>

Stir until homogeneous

Figure 1. Flow chart of the moisturizing process

\subsection{Analysis Research}




\subsubsection{Organoleptic Test}

This test is carried out by giving questionnaires to 20 respondents to physically observe the moisturizer preparations that have been formulated using the senses. Moisturizers that have been formulated are observed from the aroma, texture and color.

\subsubsection{Homogenity}

Homogeneity testing is done by placing a moisturizer between 2 petri dishes and note there are coarse homogeneous or homogeneous particles.

\subsubsection{PH measurements}

Moisturizer is put into a bottle, then the $\mathrm{pH}$ is measured using a $\mathrm{pH}$ strip indicator for acidic areas. The $\mathrm{pH}$ strip indicator is inserted into the moisturizer, then the results can be seen by matching the color of the strip with the reference color printed on the $\mathrm{pH}$ strip indicator packaging.

\subsubsection{Coverage}

Moisture as much as 0.5 grams on a petri dish which is repaired graph paper. Then each was given a weight of $0 \mathrm{~g}, 50 \mathrm{~g}, 100 \mathrm{~g}, 150 \mathrm{~g}$ and $200 \mathrm{~g}$ and left for 60 seconds. The diameter is distributed by measuring the diameter of several sides.

\subsubsection{Emulsion Stability}

The measurement of the emulsion material is inserted in the container and weighed as much as 2.5 grams, the container and materials are inserted into the oven with a temperature of $45^{\circ} \mathrm{C}$ for 1 hour, then inserted into the cooler temperature below $0^{\circ} \mathrm{C}$ for 1 hour and returned again to the oven with a temperature of $45^{\circ} \mathrm{C}$ for 1 hour. Then count the water that can not be mixed [7].

\subsubsection{Density Analysis}

The type weights are measured using a picnometer at $20^{\circ} \mathrm{C}$. Measurement of the type of weight with a pycnometer with a thermometer as follows, weighed thoroughly the empty pycnometers (A), a picnometer containing water (B), and a picnometer containing the dosage (C). The weight of the dosage type is calculated with the following formula:

$$
\mathrm{DA}=\frac{\mathrm{C}-\mathrm{A}}{\mathrm{B}-\mathrm{A}}
$$

\subsubsection{Flavonoids Test}

Quercetin standard solution with a concentration of $10 \mathrm{ppm}, 20$ ppm, $30 \mathrm{ppm}, 40 \mathrm{ppm}, 50 \mathrm{ppm}$ that has been prepared. Then each concentration of the standard dispectophotometric solution to determine its wavelength and absorbance. Determination of flavonoid levels in green grass jelly extract was carried out by dissolving $2.5 \%, 5 \%, 7.5 \%$ extract with the addition of distilled water each volume up to $10.0 \mathrm{~mL}$ and homogenized. Next pipette $1.0 \mathrm{~mL}$ of the solution into a $50 \mathrm{~mL}$ erlenmayer for 3 replications. Each solution was added with $0.1 \mathrm{~mL}$ of potassium acetate solution, $0.1 \mathrm{~mL}$ of aluminum chloride solution and $10 \mathrm{ml}$ of distilled water to be homogeneous. The solution that has been made is added and allowed to stand at room temperature for 30 minutes. After 30 minutes the solution was put into a cuvette tested on 
spectrophotometry. Absorption is measured at a wavelength of $435 \mathrm{~nm}$ and the absorbance results are obtained. Total flavonoid levels were calculated from quercetin standard solution curves. The total flavonoid content is expressed as the equivalent mg amount of quercetin per gram of extract.

\section{Results and Discussion}

The study used the concentration influence of Aloe vera extract and green grass leaves in the manufacture of moisturizing formulations. The moisturizer produced is then performed organoleptic, homogeneity, $\mathrm{pH}$ measurement, dispersion, emulsion stability analysis and specific gravity analysis.

\subsection{Organoleptik Test}

Based on the results of the tests that have been done to 20 people who tried our products, obtained the following data:

Table 1. Organoleptic observation result (color)

\begin{tabular}{|c|c|c|c|c|c|}
\hline \multirow{2}{*}{ No. } & \multirow{2}{*}{ Formulation } & \multicolumn{4}{|c|}{ Organoleptic (Color) } \\
\cline { 3 - 6 } & & White & Light Green & Concentrated Green & Dark Green \\
\hline 1. & F(A) & 20 & - & - & - \\
\hline 2. & F(B) & - & 2 & 15 & 3 \\
\hline 3. & F(C) & 20 & - & - & - \\
\hline 4. & F(D) & - & 6 & 12 & 2 \\
\hline 5. & F(E) & - & 1 & 8 & 11 \\
\hline 6. & F(F) & - & - & 2 & 18 \\
\hline
\end{tabular}

Table 2. Organoleptic observation result (texture)

\begin{tabular}{|c|c|c|c|c|c|}
\hline \multirow{2}{*}{ No. } & \multirow{2}{*}{ Formulation } & \multicolumn{4}{|c|}{ Organoleptic (Tekxture) } \\
\cline { 3 - 6 } & & Very Dilute & Dilute & Thick & Very Thick \\
\hline 1. & $\mathrm{~F}(\mathrm{~A})$ & 1 & 3 & 16 & - \\
\hline 2. & $\mathrm{~F}(\mathrm{~B})$ & - & 3 & 11 & 6 \\
\hline 3. & $\mathrm{~F}(\mathrm{C})$ & 1 & 3 & 16 & - \\
\hline 4. & $\mathrm{~F}(\mathrm{D})$ & - & 2 & 17 & 1 \\
\hline 5. & $\mathrm{~F}(\mathrm{E})$ & - & 1 & 13 & 6 \\
\hline 6. & $\mathrm{~F}(\mathrm{~F})$ & - & 1 & 12 & 7 \\
\hline
\end{tabular}

Table 3. Organoleptic observation result (scents)

\begin{tabular}{|c|c|c|c|c|c|}
\hline \multirow{2}{*}{ No } & Formulation & Perfume & $\begin{array}{c}\text { Perfume and } \\
\text { Aloe vera }\end{array}$ & $\begin{array}{c}\text { Perfume and } \\
\text { Green Grass leaf }\end{array}$ & $\begin{array}{c}\text { Perfume and } \\
\text { distinctive } \\
\text { both }\end{array}$ \\
\hline 1. & F(A) & 19 & - & 1 & - \\
\hline 2. & F(B) & - & 1 & 19 & - \\
\hline 3. & F(C) & 10 & 9 & 1 & - \\
\hline 4. & F(D) & - & - & 10 & 10 \\
\hline 5. & F(E) & - & - & 10 & 10 \\
\hline 6. & F(F) & - & 3 & 8 & 9 \\
\hline
\end{tabular}

Data obtained from organoleptic tests are color, aroma, and texture. The color organoleptic test results are F (A) without the addition of green grass jelly 
and aloe vera has a white color. F (B) with the addition of $2.5 \%$ grass jelly is dark green because there is chlorophyll content in grass jelly so it makes physical changes to the moisturizing preparation. F (C) with the addition of grass jelly $0 \%$ and aloe vera $2.5 \%$ has a white color because the aloe gel is white and there is no discoloration. F (D) with the addition of $2.5 \%$ grass jelly and $5 \%$ aloe vera has a dark green color due to the chlorophyll content of grass jelly although the addition of aloe vera has no color effect because the aloe vera has a clear white color. F (E) with the addition of $5 \%$ grass jelly and $7.5 \%$ aloe vera has a deep green color because the concentration of grass jelly is quite large. $\mathrm{F}(\mathrm{E})$ with the addition of $7.5 \%$ grass jelly and $10 \%$ aloe vera has a dark green color because there is an addition to the concentration of grass jelly extract. From the color organoleptic test that samples $\mathrm{F}(\mathrm{A})$ and $\mathrm{F}(\mathrm{C})$ have a more attractive color.

Organoleptic texture test results are samples F (A) to sample F (B) all have a thick texture because of the composition of cetyl alcohol as an emulgator and the addition of grass jelly + aloe vera has no effect on the texture of moisturizing preparations. The organoleptic scent test results are F (A) nonsample moisturizers having a perfume aroma added during the moisturizing process. $\mathrm{F}(\mathrm{B})$ with the addition of $2.5 \%$ grass jelly and $0 \%$ aloe vera scented perfume and grass jelly because of the addition of grass jelly extract concentration. $\mathrm{F}(\mathrm{C})$ with the addition of $0 \%$ grass jelly and $2.5 \%$ aloe vera scented perfume because the concentration of aloe vera is inserted less so that the aroma of aloe vera is also lacking. $F(D)$ with the addition of $2.5 \%$ grass jelly $+5 \%$ aloe vera and $\mathrm{F}(\mathrm{E})$ with the addition of $5 \%$ grass jelly $+7.5 \%$ aloe vera have the scent of grass jelly and the characteristic aroma of both is the grass jelly and aloe vera because there is no dominating aroma so the aroma is the same. $\mathrm{F}(\mathrm{F})$ with the addition of $7.5 \%$ grass jelly and $10 \%$ aloe vera has the characteristic aroma of both grass jelly + aloe vera. From organoleptic tests the preferred aroma is F (A) because the repondents think that the other formulations are thicker and the colors are less.

\subsection{Homogenity}

From the experiments it can be seen that all samples made from green grass jelly moisturizers and the addition of aloe vera have homogeneous properties because the active ingredients in the moisturizing preparations have been spread evenly. In accordance (SNI-16-4399-1996) moisturizer that is the appearance of a moisturizer is homogeneous.

\subsection{PH measurement}

Based on the results of the tests obtained the following data:

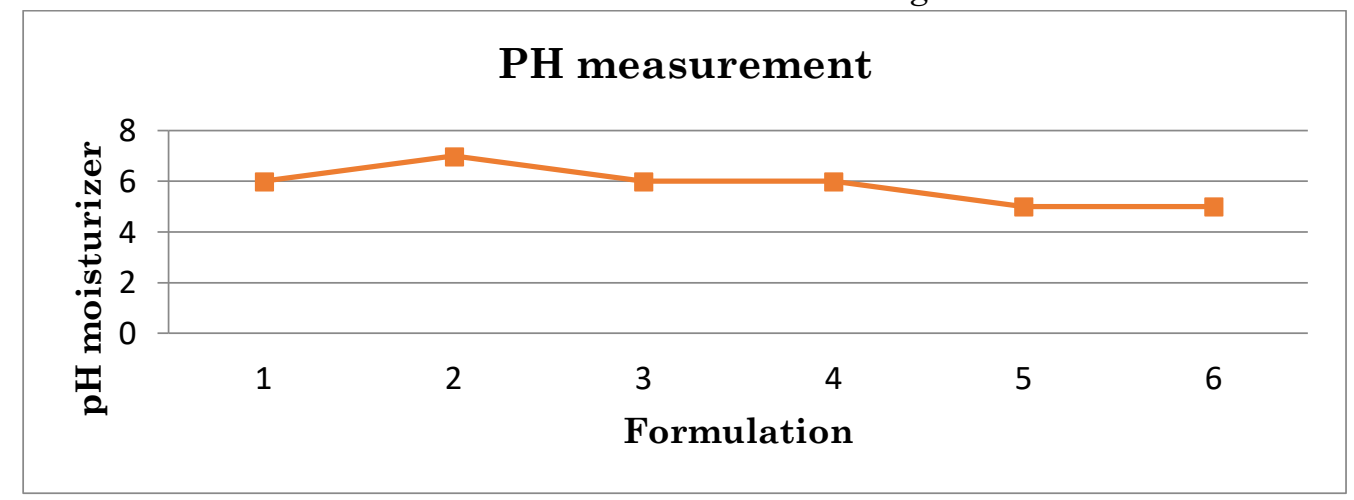

Figure 2. Chart of $\mathrm{pH}$ acidity degree test

Based on the graph that looks visible on the $\mathrm{pH}$ obtained in the range 5-7 in accordance with the provisions (SNI-16-4399-1996), namely 4.5-8. 
The lowest $\mathrm{pH}$ measurements were obtained on $\mathrm{F}(\mathrm{E})$ and $\mathrm{F}(\mathrm{F})$ with varying concentrations of $\mathrm{F}(\mathrm{E}) 5 \%$ green grass jelly $+7.5 \%$ aloe vera and $7.5 \%$ green grass jelly $+10 \%$ aloe vera while the value The highest $\mathrm{pH}$ was obtained at F (B) with a variation of green grass jelly concentration of $2.5 \%$. The data above shows that the grass jelly moisturizer + aloe vera can be used and does not cause scaly skin or skin irritation.

\subsection{Test Coverage}

In the coverage test, each sample obtained the following data:

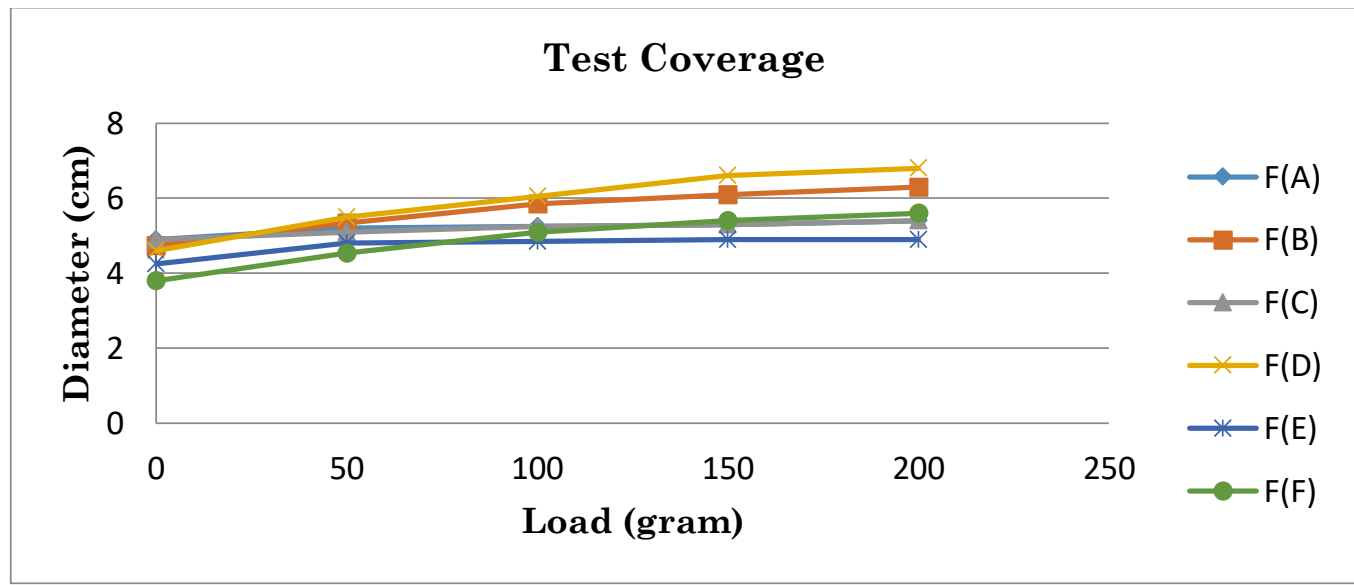

Figure 3. Scatter power graph

Table 4. Scatter power test results

\begin{tabular}{|c|c|c|c|c|c|c|c|}
\hline \multirow{2}{*}{ No. } & \multirow{2}{*}{ Formulation } & \multicolumn{5}{|c|}{ Diameter(cm) } & \multirow{2}{*}{ Average } \\
\cline { 3 - 7 } & & $0 \mathrm{~g}$ & $50 \mathrm{~g}$ & $100 \mathrm{~g}$ & $150 \mathrm{~g}$ & $200 \mathrm{~g}$ & \\
\hline 1. & $\mathrm{~F}(\mathrm{~A})$ & 4,9 & 5,2 & 5,25 & 5,3 & 5,4 & 5,21 \\
\hline 2. & $\mathrm{~F}(\mathrm{~B})$ & 4,75 & 5,35 & 5,85 & 6,1 & 6,3 & 5,67 \\
\hline 3. & $\mathrm{~F}(\mathrm{C})$ & 4,9 & 5,1 & 5,25 & 5,3 & 5,4 & 5,19 \\
\hline 4. & $\mathrm{~F}(\mathrm{D})$ & 4,6 & 5,5 & 6,05 & 6,6 & 6,8 & 5,91 \\
\hline 5. & $\mathrm{~F}(\mathrm{E})$ & 4,25 & 4,8 & 4,85 & 4,9 & 4,9 & 4,74 \\
\hline 6. & $\mathrm{~F}(\mathrm{~F})$ & 3,8 & 4,55 & 5,1 & 5,4 & 5,6 & 4,89 \\
\hline
\end{tabular}

From the data above shows that the greatest spread is on the formulation $\mathrm{F}$ (D), namely grass jelly $2.5 \%$ and aloe vera $5 \%$, and the smallest spread is F (E), namely grass jelly $5 \%$ and grass jelly $7.5 \%$. Samples F (E) and samples F (F) have a small value of the dispersal power because at the time of preparation the moisturizer is re-fused so that the viscosity is large. The difference in spreadability, due to the difference in viscosity factor in each preparation formula, the greater the viscosity, the smaller the spread of the moisturizing resistance. Therefore sample F (A) to sample F (D) has a fairly good dispersion. A good spread test is $5-7 \mathrm{~cm} \mathrm{[8].}$ 


\subsection{Emulsion Stability Analysis}

The measurement of emulsion stability in the experiment showed the same result that is $100 \%$. The results showed no changes in the emulsion during storage at room temperature $\left(30^{\circ} \mathrm{C}\right)$, including the separation between the dispersed phase and the dispersing phase, did not cause sediment, emulsion cracking and gel formation as well as the absence of aroma and color changes after the testing process emulsion stability is done. This is presumably because the resulting emulsion has room temperature storage so that the stability of the skin moisturizing emulsion produced is the same and shows signs of a stable emulsion.

\subsection{Specific Gravity Analysis}

Specific gravity testing for each sample obtained the following data:

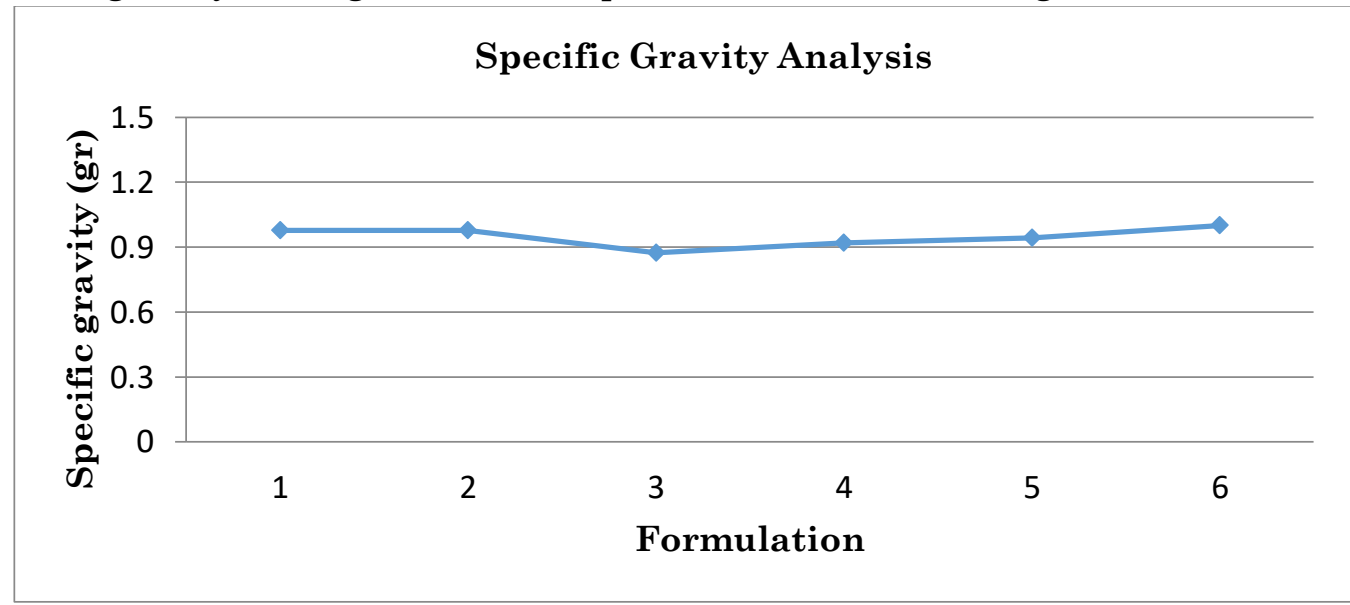

Figure 4. Specific gravity graph

Table 5. Specific gravity test results

\begin{tabular}{|c|c|c|}
\hline No & Formulation & Specific Gravity $(\mathrm{gr})$ \\
\hline 1. & $\mathrm{~F}(\mathrm{~A})$ & 0,977 \\
\hline 2. & $\mathrm{~F}(\mathrm{~B})$ & 0,976 \\
\hline 3. & $\mathrm{~F}(\mathrm{C})$ & 0,874 \\
\hline 4. & $\mathrm{~F}(\mathrm{D})$ & 0,918 \\
\hline 5. & $\mathrm{~F}(\mathrm{E})$ & 0,942 \\
\hline 6. & $\mathrm{~F}(\mathrm{~F})$ & 1,00 \\
\hline
\end{tabular}

From the results above in the sample $\mathrm{F}(\mathrm{C})$ showed that the decrease in specific gravity due to the concentration of aloe which is added is relatively small in the moisturizing preparations so that the concentration also has a small effect on specific gravity. However, the samples F (D) to F (F) and samples F (A) - F (B) experienced an increase in specific gravity. The higher the concentration of grass jelly extract and aloe vera extract the greater the density value. Based on SNI 164399-1996 specific gravity has a standard that is $0.95-1.05 \mathrm{~g} / \mathrm{ml}$. Although the moisturizing preparations have increased in specific gravity, there are some moisturizing preparations which are not in accordance with SNI, namely F (C), F (D) and F (E) are still below the SNI value.

\subsection{Flavanoid Test}

Flavonoids are natural compounds with potential as antioxidants that can ward off free radicals. Determination of total fl avanoid content, using quersetin 
as a comparison solution. Quersetin will react with $\mathrm{AlCl} 3$ so that the maximum wavelength shift occurs, it is necessary to determine the maximum wavelength by looking at the absorption spectrum. The maximum wavelength results obtained at $435 \mathrm{~nm}$ [9]. As well as the addition of potassium acetate which aims to maintain maximum wavelengths [10]. The following are the absorbance data obtained from the study:

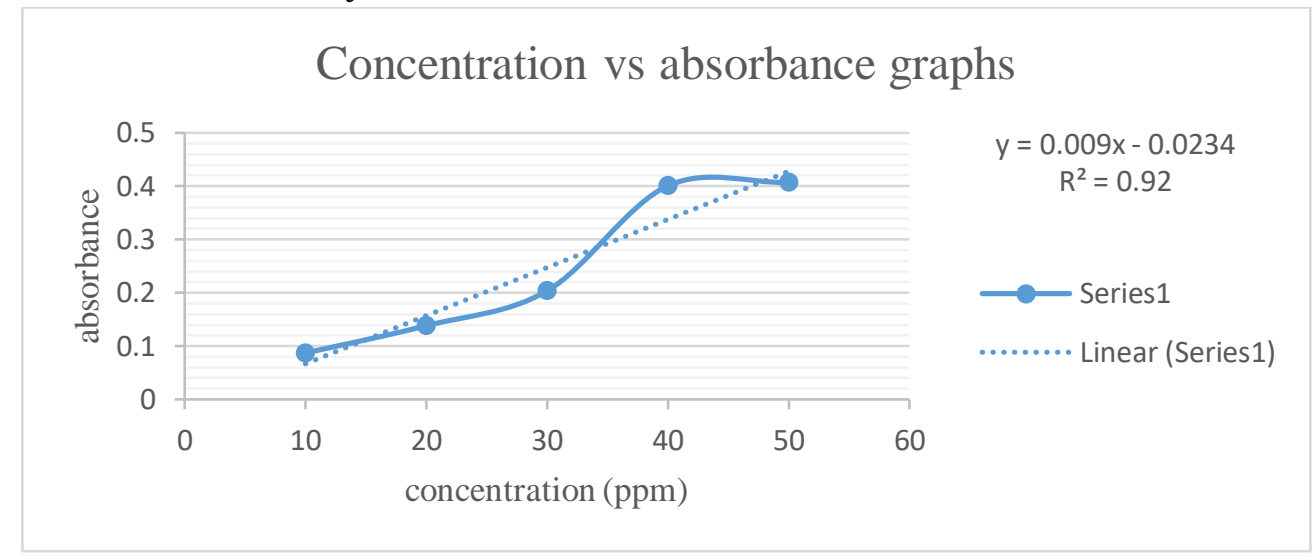

Figure 5. Specific gravity graph

Table 6. Quercetin absorbance results

\begin{tabular}{l|c|c|c|}
\cline { 2 - 4 } & No & Concentration $(\mathrm{ppm})$ & Absorbance $\left(\mathrm{A}^{\circ}\right)$ \\
\cline { 2 - 4 } & 1 & 10 & 0,087 \\
\cline { 2 - 4 } he & 2 & 20 & 0,1383 \\
\cline { 2 - 4 } dat & 3 & 30 & 0,2036 \\
\cline { 2 - 4 } a & 4 & 40 & 0,4006 \\
\cline { 2 - 4 } abo & 5 & 50 & 0,407 \\
\cline { 2 - 4 } & \multicolumn{2}{|c}{}
\end{tabular}

ve is known equation that is $\mathrm{y}=0.009 \mathrm{x}-0.0234$ and the correlation coefficient $(\mathrm{R} 2)=0.92$ to determine the strong, moderate, or weak relationship between the variables studied. Then look for absorbance data of green grass jelly samples using spectrophotometry, the absorbance results are entered into the equation $\mathrm{y}=$ $0.009 \mathrm{x}-0.0234$ as the value of $\mathrm{y}$. The following is the absorbance value and the result of flavonoid levels:

Table 7. Green grass absorbancy and flovanoid content result data

\begin{tabular}{|c|c|c|c|}
\hline No. & Concentrarion (\%) & Absorbance $\left(\mathrm{A}^{\circ}\right)$ & Flavanoid levels (ppm) \\
\hline 1 & 2,5 & 0,32 & 38,15556 \\
\hline 2 & 5 & 0,55 & 63,71111 \\
\hline 3 & 7,5 & 0,64 & 73,71111 \\
\hline
\end{tabular}

The results of $\mathrm{fl}$ avonoid levels were obtained at grass jelly concentrations of $2.5 \%, 5 \%$ and $7.5 \%$ obtained levels of flavonoids $38.15556,63.71111$, and $73.71111 \mathrm{mg}$ of quercetin equivalent per gram of extract. Determination of total flavonoid levels was carried out to determine the amount of flavonoid contained in green grass jelly extract. 


\section{Conclusion}

Based on the research results of moisturizers from green grass jelly with the addition of aloe vera on the quality of the moisturizer it can be concluded that:

1. Organoleptic test of all parameters (color, aroma, texture) found that the respondents preferred moisturizer and the best spread was moisturizer F (D) with a concentration of green grass jelly $2.5 \%$ and aloe vera $5 \%$.

2. Moisture formulations $\mathrm{F}(\mathrm{A})$ to $\mathrm{F}(\mathrm{F})$ on the parameters of homogeneity, humidifying $\mathrm{pH}$, and analysis of emulsion stability have met the SNI-16-4399-1996 quality requirements.

3. Moisturizers on specific gravity parameters that meet SNI-16-4399-1996 quality requirements are non-sample $F(A)$ moisturizers, $F(B)$ with green grass jelly concentrations of $2.5 \%$ and $\mathrm{F}(\mathrm{F})$ with green grass jelly concentrations of $7,5 \%$ and aloe vera $10 \%$

4. The largest flavanoid content in green grass jelly is a concentration of $7.5 \%$ with a flavanoid level of $73.11 \mathrm{mg}$ equivalent to quercetin per gram of extract can act as an antioxidant.

\section{References}

[1] S. Maysuhara., Rahasia Cantik, Sehat dan Awet Muda. Pustaka Panasea. Yogyakarta. 2009.

[2] S. Purwaningsih,. S. Ella., and A.B. Tika,. "Formulasi Skin Lotion dengan Penambahan Karagenan dan Antioksidan Alami dari Rhizophora mucronata Lamk." Jurnal Akuatika. 5 (1) : 55-62. 2014.

[3] R. Aryani,. "Formulasi dan Uji Stabilitas Krim Kombinasi Alfa Tokoferol Asetat dan Etil Vitamin C Sebagai Pelembab Kulit." Jurnal Kesehatan Bakti Tunas Husada. 13(1) : 213-227. 2015.

[4] N. Khoiriyah,. dan L. Amalia,. "Formulasi Cincau Jelly Drink (Premna oblongifolia L Merr)." Jurnal Gizi Dan Pangan. 9(2): 73 - 80. 2014.

[5] I. Santi,. P. Bayu,. dan W. Sri,. "Uji Efek Ekstrak Etanol Daun Cincau Hijau (Cyclea barbata Miers) Sebagai Anti Inflamasi Pada Tikus Putih Yang Diinduksi Karagen." 9 (1) 58-66. 2017.

[6] U.K. Damhas,. "Efektivitas Campuran Ekstrak Aloe Vera dan Tea Tree Oil dalam Formulasi Pelembab pada Kekeringan Kulit." Tesis. Fakultas Kedokteran.Universitas Diponegoro. Semarang. 2015.

[7] H.E.Fitriani,. S.W. Eko dan Syawaalz A,. "Pengaruh Konsentrasi Pektin Dalam Suhu Dan Waktu Penyimpanan Berbeda Terhadap Karakteristik Pelembab Kulit." Jurnal Sains Natural Universitas Nusa Bangsa. 4 (2) : 187 - 200. 2014.

[8] T. Mulyani, A. Herda,. Rahimah. dan R. Selvi,. "Formulasi dan Aktivitas Antioksidan Lotion Ekstrak Daun Suruhan (Peperomia pellucida L.)." Journal of Current Pharmaceutical Sciences. 2(1): 111-117. 2018.

[9] E. Gangga, R. Purwati, Y. Farida, dan Kartiningsih. "Penetapan Parameter Mutu Ekstrak yang Memiliki Aktivitas sebagai Antioksidan dari Daun Cincau Hijau (Cyclea barbata L.Miers.)." Jurnal Ilmu Kefarmasian Indonesia. 15(2): 236-243. 2017.

[10] Aminah., N. Tomayahu, dan Z. Abidin, "Penetapan Kadar Flavanoid Total Ekstrak Etanol Kulit Buah Alpukat (Persea Americana Mill) dengan Metode Spektrofotometri UV-VIS." Jurnal Farmasi. 4(2): 226-230. 2017. 